Mariusz Makowski

Uniwersytet Ekonomiczny w Krakowie, Polska - University of Economics in Cracow, Poland

\title{
Determinanty przedsiębiorczości w opinii nauczycieli i przedsiębiorców. Konkluzje i praktyczne wskazania z programu Perspective
}

\author{
Determinants of Entrepreneurship in the Perspective of Teachers and Entrepreneurs. \\ Conclusions and Practical Guidelines from Perspective Program
}

Streszczenie: Program Perspective (Leonardo da Vinci), realizowany w latach 2013-2015 przez ośmiu partnerów europejskich, poświęcony był udoskonalaniu metod kształcenia nauczycieli pod kątem przedsiębiorczości. W artykule zaprezentowano efekty finalnego etapu projektu, jakim było przeprowadzenie czterech grup fokusowych, w których wzięli udział nauczyciele, przedsiębiorcy, przedstawiciele władz samorządowych, trenerzy oraz dyrektorzy szkół. W grupach tych poszukiwano czynników, które mogą sprzyjać rozwojowi postaw przedsiębiorczych zarówno uczniów, jak i nauczycieli. Próbowano również diagnozować przeszkody i trudności, które należy pokonać, aby tworzyć środowisko edukacyjne bardziej przyjazne budowaniu postaw przedsiębiorczych. Kolejnym celem tych spotkań było określenie warunków sprzyjających szkoleniu facylitatorów przedsiębiorczości. Z badań tych wyłania się obraz szeregu postulatów dla zmian w systemie edukacji, w szczególności dotyczących doboru i szkolenia kadry nauczycielskiej. W artykule przedstawiono listę rekomendacji zgłaszanych przez nauczycieli i przedsiębiorców, jak również komentarz autora.

\begin{abstract}
Perspective (Leonardo da Vinci) program, implemented in 2013-2015 by eight European partners, was devoted to improving methods of teachers' education for entrepreneurship. The article presents the results of the final phase of the project which comprised four focus groups. They were attended by teachers, entrepreneurs, representatives of local authorities, coaches and principals. Participants of these groups looked for factors that may favor the development of entrepreneurial attitudes of pupils and teachers. There were also attempts made to diagnose the obstacles and difficulties that must be overcame to create more friendly learning environment supporting building entrepreneurial attitudes. Another objective of these meetings was to determine the conditions that foster trainings of entrepreneurship facilitators. The outcome of these studies draws a picture of series of demands for changes in the education system, particularly in the area of selection and trainings of teachers. The article presents a list of recommendations reported by teachers and entrepreneurs, as well as the author's comment.
\end{abstract}

Słowa kluczowe: kompetencje; nauczyciel; program; przedsiębiorczość; szkolenie; szkoła Key words: competences; curriculum; entrepreneurship; school; teacher; training 
Otrzymano: 25 października 2015

Received: 25 October 2015

Zaakceptowano: 21 kwietnia 2016

Accepted: 21 April 2016

\section{Sugerowana cytacja/Suggested citation:}

Makowski, M. (2016). Determinanty przedsiębiorczości w opinii nauczycieli i przedsiębiorców. Konkluzje i praktyczne wskazania z programu Perspective. Przedsiębiorczość - Edukacja, 12, 378-390.

\section{Wstęp}

Niniejszy artykuł stanowi próbę syntezy danych zebranych w projekcie Perspective, międzynarodowym programie edukacyjnym finansowanym ze środków Unii Europejskiej. Autor prowadził w nim działania badawcze i szkoleniowe ${ }^{1}$. Program ten był poświęcony doskonaleniu metod kształcenia nauczycieli oraz budowaniu ducha przedsiębiorczości (ang. entrepreneurial spirit). Koordynatorem projektu była włoska organizacja TUCEP z siedzibą w Perugii. W programie (w latach 2013-2015) uczestniczyło - łącznie z Polską - osiem krajów Unii Europejskiej: Włochy, Holandia, Węgry, Belgia, Austria, Grecja oraz Portugalia. W każdym z tych krajów przeprowadzono analogiczny program badawczo-szkoleniowy, w którym wyznaczono cztery kluczowe cele:

1. Wykonanie analizy kontekstowej diagnozującej sytuację edukacji nauczycieli w Europie w kontekście przedsiębiorczości. Mieściły się w niej: analiza roli nauczycieli w różnych krajach europejskich, a także analiza narodowych strategii, dobrych praktyk i doświadczeń z działań pilotażowych oraz przykłady sukcesów edukacyjnych, metodologii wykorzystywanej w edukacji nauczycieli w zakresie przedsiębiorczości, podejść i narzędzi stosowanych w celu przyjęcia roli facilitatora, podstawowych kompetencji w dziedzinie przedsiębiorczości, stałego rozwoju zawodowego nauczycieli w UE.

2. Przeprowadzenie szkoleń nauczycieli i studentów - spotkań w ramach study circles - „kół uczenia się" z wykorzystaniem metodologii uczenia się od siebie (ang. peer learning), adresowanych do nauczycieli szkół podstawowych i ponadpodstawowych, jak również do praktykantów w tych placówkach. Miały one służyć wsparciu rozwoju ich umiejętności i metod wykorzystywanych w uczeniu przedsiębiorczości w ramach różnych przedmiotów i w różnych kontekstach.

3. Opracowanie Wirtualnego Środowiska Uczenia się (ang. Virtual Learning Environment - VLE), aplikacji on-line, obejmującej materiały szkoleniowe, wskazówki dla nauczycieli, przykłady dobrych praktyk (w różnych obszarach, dla różnych poziomów i typów edukacji). Celem tej strony jest udostępnienie nauczycielom interaktywnych narzędzi pozwalających na dzielenie się doświadczeniem, a także rozpowszechnianie pomysłów i metod dotyczących edukacji w zakresie przedsiębiorczości².

4. Przeprowadzenie spotkań (grup fokusowych) z przedsiębiorcami, menedżerami, szkoleniowcami, dyrektorami szkół oraz przedstawicielami władz samorządowych celem określenia głównych wyzwań, barier i szans dla przedsiębiorczości, finalnie zaś - zgromadzenie rekomendacji dla edukacji w duchu przedsiębiorczości.

\footnotetext{
${ }^{1}$ PERSPECTIVES - Experiences Entrepreneurial Spirit Challenge in School Education Project n. 540455-LLP1-2013-1-IT-COMENIUS-CMP.

${ }^{2}$ Ze strony http://www.perspectiveproject.eu/pl mogą korzystać również polscy nauczyciele; część materiałów dostępna jest w języku polskim.
} 
W założeniu program służyć miał nauczycielom oraz studentom przygotowującym się do tego zawodu. Cykl szkoleń adresowany był do uczących na wszystkich szczeblach edukacji szkolnej (z wyłączeniem edukacji akademickiej). Jego celem strategicznym było takie kształtowanie postaw i przekonań uczących, by przekazywali je oni dalej - uczniom, innym nauczycielom, rodzicom - stając się swoistymi facylitatorami przedsiębiorczości. Status facylitatora wymaga tu pewnego wyjaśnienia. Działania wynikające z projektu Perspective nie koncentrowały się na specyficznym, ujętym w ramy programowe przedmiocie podstawy przedsiębiorczości. Przede wszystkim chodziło w nich o edukację nauczycieli, aby w przedsiębiorczy sposób uczyli oni wszystkich przedmiotów. Facylitator przedsiębiorczości może być formalnie nauczycielem, lecz nie jest to wymóg konieczny. Również nie każdy nauczyciel jest $\mathrm{z}$ automatu facylitatorem. Rola ta wiąże się ze zdolnością inspirowania innych, m.in. przez własne przedsiębiorcze działanie. W roli nauczycielskiej może się ono wiązać z niezależnością, gospodarnością, innowacyjnością, kreatywnością czy oryginalnością. Na finalnym etapie programu, podczas przeprowadzonych spotkań fokusowych z nauczycielami i przedsiębiorcami, pytano uczestników m.in. o cechy środowiska edukacyjnego, które sprzyjałyby szkoleniu facylitatorów, jak również o przymioty i kompetencje, jakimi facylitator powinien się odznaczać.

Istotne jest też określenie, jak w programie Perspective rozumiano przedsiębiorczość. Pojęcie to było traktowane szeroko, jako podstawowa zdolność do kreowania i zaspokajania własnych oraz cudzych potrzeb, odbywająca się w każdych warunkach, jakie stawia otoczenie (Gregorczyk i in., 2007). Wiązano ją z działaniem proaktywnym, czyli takim, w którym podejmuje się inicjatywę i ryzyko zmiany, bazuje na wewnętrznym umiejscowieniu kontroli, rozwija motywację wewnętrzną, przewiduje przyszłe wyzwania, aktywnie wpływa na otoczenie i angażuje w zmianę warunków swojego życia (Wypych, 2012).

Poniżej zostaną przedstawione wnioski z ostatniego etapu działań w programie Perspective, $\mathrm{z}$ czterech spotkań w ramach grup fokusowych.

\section{Cel i metoda badania}

Celem badania było ustalenie barier, które istnieją w edukowaniu przedsiębiorczości, oraz zebranie propozycji, jak można te bariery pokonać. Równocześnie postanowiono zebrać od przedstawicieli różnych środowisk rekomendacje dotyczące kształtowania postaw przedsiębiorczych.

Badanie miało charakter jakościowy z wykorzystaniem metody wywiadów grupowych grup fokusowych. Badanie z użyciem grup fokusowych jest cenną metodą pozyskiwania danych, które trudno byłoby zgromadzić za pomocą metod ilościowych (por. Morgan, 1998). Zarówno czynniki związane z rekrutacją do grupy (zespoły ekspertów w danym zagadnieniu), jak i zjawiska związane z dynamiką grupy (zwiększenie kreatywności, wzajemna inspiracja, wzajemne uczenie się) czynią ustrukturyzowane wywiady w grupach fokusowych wartościową metodą badań.

Wywiady przeprowadzono według standardowych wymogów tej procedury (Blank, 2015). Liczebność uczestników w poszczególnych grupach wynosiła 6 osób (rekomendacja: 6-8), a czas trwania spotkania -2 godziny. Rolę facylitatora odgrywał w nich autor. Rekrutacja do grup odbywała się w oparciu o zidentyfikowane uprzednio związki nauczycieli, menedżerów i urzędników z szeroko rozumianą działalnością przedsiębiorczą. Znaleźli się tu: nauczyciele przedmiotu podstawy przedsiębiorczości, nauczyciele szczególnie aktywni w tej dziedzinie (laureaci konkursów, stażyści programów zagranicznych), uczący w szkołach, które realizują 
nowatorskie programy, wykładowca uczelni pedagogicznej, wykładowca specjalizujący się w innowacyjnych technikach nauczania, autor gier ekonomicznych, radna miejska od lat zajmująca się tematyką oświatową, przedsiębiorcy rekrutujący do pracy absolwentów uczelni, psychologowie - trenerzy zajmujący się rozwijaniem umiejętności społecznych, motywacji oraz pracy w grupie. Tego rodzaju dobór uczestników podyktowany był celem uzyskania możliwie jak najszerszej perspektywy dotyczącej podjętej tematyki. Realizowano go przez pozyskanie osób funkcjonujących zarówno wewnątrz systemu szkolnictwa, jak i tych, pozostających poza szkołą, posiadających spojrzenie na analizowane zagadnienie z większego dystansu.

Cele spotkań grup fokusowych zdefiniowano następująco:

1. Wskazanie czynników, które mogą sprzyjać rozwojowi postaw przedsiębiorczych zarówno uczniów, jak i nauczycieli.

2. Diagnoza przeszkód i trudności, które należy pokonać, aby stworzyć środowisko edukacyjne bardziej przyjazne budowaniu postaw przedsiębiorczych.

3. Określenie warunków, które sprzyjałyby szkoleniu facylitatorów przedsiębiorczości.

W spotkaniach, które odbyły się na Uniwersytecie Ekonomicznym w Krakowie w okresie od maja do lipca 2015 r., wzięły udział 24 osoby. Pierwsze dwa spotkania przeznaczone były dla nauczycieli, a kolejne dwa dla przedsiębiorców i innych osób niezwiązanych bezpośrednio z pracą w szkole. Rekrutację zróżnicowano pod kątem szczebla systemu edukacji. W związku z tym w grupie „nauczycielskiej” znaleźli się: nauczyciele ze szkół podstawowych (2), nauczyciele z gimnazjum (2), nauczyciele uczący w liceum (2) oraz nauczyciele akademiccy (2), a w grupie „przedsiębiorców” - dyrektor zespołu szkół, radna Miasta Krakowa, profesor Uniwersytetu Pedagogicznego, przedsiębiorcy branży usług (6), menedżerowie (3), a także trenerzy (psychologowie) (2). Uczestnikami spotkań były osoby, które pozytywnie odpowiedziały na zaproszenie (drogą mailową i telefoniczną). Wysłano ok. 40 zaproszeń do wybranych potencjalnych uczestników. Każde z czterech spotkań trwało ok. 2 godzin i było rejestrowane na magnetofonie. Późniejsze wnioski i rekomendacje zebrano w oparciu o stenogramy z poszczególnych spotkań.

Opracowania wyników dokonano według procedury trzech elementów: podsumowanie, analiza, pisemna rejestracja (ang. summarize, analyse, report) (Eliot \& Associates, 2005). Po spisaniu nagrań dźwiękowych dokonano korekty stylistyczno-gramatycznej. Część wypowiedzi, nieistotnych z punktu widzenia celu przeprowadzanych wywiadów, odsunięto od dalszej analizy. Następnie opracowano wypowiedzi w taki sposób, aby korespondowały z postawionymi na spotkaniach pytaniami badawczymi. Tworząc raport, wybrano formułę prezentacji w punktach przedstawiających zgłoszone spostrzeżenia i rekomendacje. W dalszej części artykułu wypowiedzi te poddano interpretacji.

Wyniki - propozycje i rekomendacje

\section{Grupy fokusowe 1-2 („nauczyciele”)}

1. Określenie w programie celów pracy nauczycieli, współpraca nauczycieli różnych ścieżek przedmiotowych, tak aby zaistniała wspólna aktywność przedstawicieli różnych dyscyplin. Znaczenie transferu umiejętności z jednego przedmiotu do drugiego. Ogólny cel strategiczny: szkoła bardziej holistyczna.

2. Sformułowanie celów - czym miałaby być przedsiębiorczość na poszczególnych etapach nauczania. Uwzględnienie możliwości rozwojowych uczniów. 
3. Skłanianie dyrektorów placówek, aby tworzyli przychylny klimat dla samodzielnego tworzenia przez nauczycieli programów przedmiotowych.

4. Zaproponowanie zadania, jak można zminimalizować czas wykorzystywany na przekazywanie wiedzy przez nauczyciela (metody podawcze), aby odzyskać czas na aktywność uczniów (ang. more pupils' speaking time).

5. Syntezowanie wiedzy $\mathrm{z}$ różnych dziedzin w czasie realizacji konkretnych przedmiotów (np. program Interblok ${ }^{3}$ ), aplikacja zasady, „eksperyment może się nie udać”. Konieczność wcześniejszego przeszkolenia nauczycieli do prowadzenia tego rodzaju holistycznosyntezująco-eksperymentalnych lekcji.

6. Na poziomie systemowo-organizacyjnym należy zabiegać o formowanie mniej licznych klas, liczących nie więcej niż 20 osób.

7. Edukowanie rodziców, jak również zarządzających placówkami oświaty w kwestii statusu nauczyciela i obszarów jego oceny, tak aby ocena ta była bardziej zróżnicowana. Przykładowo, w miejsce typowego, dwubiegunowego kryterium „wymagający - niewymagający” lub „doświadczony - niedoświadczony” otwarcie pola dla zniuansowanej ewaluacji. Sferami oceny powinny stać się m.in. osobowość nauczyciela, jego cechy przedsiębiorcze, poziom i rodzaj motywacji, dokonania pozaszkolne, chęć szkolenia się i otwartość na nowe trendy.

8. Oferowanie nauczycielom urlopów stażowych, tak aby mogli spróbować swych sił w innym środowisku i kontekście zawodowym, aby nabrali doświadczeń w działalności gospodarczej lub choćby organizatorskiej. Zapewnienie im - w tym kontekście - gwarancji nienaruszalności ich miejsca pracy. Urlop powinien być integralnym składnikiem ścieżki rozwoju zawodowego, a nie rodzajem nagrody lub kary, a także składnikiem polityki personalnej szkoły.

9. Wysyłanie studentów uczelni pedagogicznych na praktyki nie tylko do szkół, lecz także do firm.

10. Stworzenie bodźców rozwojowych dla nauczycieli czynnych w zawodzie (dobrowolność i możliwość wyboru rodzaju szkoleń dla nauczycieli). Porzucenie reguły obowiązkowości szkoleń i tego, że ich zakres, temat jest narzucany odgórnie.

11. Uczynienie placówek oświaty polem silniejszego oddziaływania postawotwórczego ze względu na to, że w Polsce udział środowiska rodzinnego jest dominujący, co ma przełożenie na tworzenie postaw kontrprzedsiębiorczych. Wchodzą tu w grę takie czynniki, jak zachęcanie do rywalizacji, nadopiekuńczość, roszczeniowość, niesamodzielność, infantylizm.

12. Promowanie międzynarodowej wymiany nauczycieli na wszystkich szczeblach nauczania (np. program Erasmus+), co umożliwi uczącym obserwację innych rozwiązań organizacyjnych, stylów uczenia, kultury organizacyjnej, rozwiązań logistyczno-architektonicznych, jak również poznawanie innych kultur, mentalności, systemów wartości.

13. Zwiększenie udziału i podnoszenie statusu nauki języków obcych na uczelniach przygotowujących do zawodu nauczyciela. Znajomość języków obcych jest bowiem kluczowym prerekwizytem do korzystania z wymian międzynarodowych oraz z materiałów edukacyjno-szkoleniowych tworzonych w wielu programach Unii Europejskiej.

14. Pokazywanie w mediach oraz prezentowanie w szkole success stories nauczycieli, którzy odnieśli sukces. Chodzi tu zarówno o dokonania nauczycieli, jak i o sukcesy odniesione przez ich uczniów. Przedstawianie nauczyciela jako „ojca sukcesu”.

\footnotetext{
${ }^{3}$ Program Interblok autorstwa W. Kwiatka i I. Wrońskiego jest realizowany w ok. 50 szkołach w Polsce (stan na październik 2015 r.). Stosuje się go m.in. w Społecznym Towarzystwie Oświatowym (zespół szkół) im. Juliusza Słowackiego w Krakowie.
} 
15. Aplikacja koncepcji inteligencji wielorakiej (ang. multiple intelligences) w szkołach, wyjście poza standardowe (testowe) rozumienie inteligencji, dowartościowanie inteligencji wielorakich. Szkolenie nauczycieli w taki sposób, aby stawali się specjalistami od diagnozowania tego rodzaju talentów.

16. W czasie finałów konkursów promowania najlepszych nauczycieli stworzenie miejsca forum dla pokazywania dobrych praktyk. Istotne jest też dowartościowanie zaangażowania nauczycieli oraz ich wysiłków wykraczających poza standardowe obowiązki.

17. Wskazana jest zmiana sposobu nauczania psychologii na studiach pedagogicznych - powinno być mniej teorii, a więcej praktyki.

18. Konieczna jest całkowita zmiana systemu praktyk studenckich (głos nauczyciela: „praktyki w polskich uczelniach to fikcja”). Na praktykach adepci zawodu nauczyciela powinni zajmować się poznawaniem uczniów jako młodych ludzi, powinni uczyć się, jak z nimi rozmawiać, jak ich motywować, w jaki sposób rozwiązywać problemy, a także „rozgrywać" konflikty. Niezbędne są tu kluczowe kompetencje psychologiczne u studentów.

19. Odejście od stylu zarządzania pracą nauczycieli/szkoły według paradygmatu „wszystko musi wyjść na 100\%”. Rozluźnienie podejścia do realizacji wytycznych programu, stworzenie przestrzeni pewnej wolności dla eksperymentowania, pojawiania się błędów, proponowania udoskonaleń i dla elastycznego podejścia.

20. Facylitator przedsiębiorczości powinien charakteryzować się takimi cechami, jak: kreatywność, empatyczność, zdolność słuchania innych, doświadczenie z innego systemu edukacyjnego (zagranica) lub systemu pracy (korporacja, służby społeczne, własny biznes).

21. Zmiana zasad funkcjonowania wolontariatu w szkole - aktualnie wielu uczniów angażuje się bowiem w tę formę aktywności z myślą o pozyskaniu punktów do oceny z zachowania, czyli w oparciu o motywację zewnętrzną.

22. Najbardziej pożądana cecha facylitatora/nauczyciela to „partnerskość”, czyli zdolność tworzenia partnerskich relacji z uczniem, który formalnie odgrywa rolę podrzędną. Kandydatów do zawodu należy rekrutować z uwzględnieniem tej predyspozycji, która następnie w toku studiów i praktyk powinna być rozwijana. Ponadto powinna być to główna cecha, na którą zwraca się uwagę w trakcie procedury doboru osób mających zostać facylitatorami przedsiębiorczości.

23. Angażowanie wybitnie uzdolnionych uczniów do współprowadzenia z nauczycielem lekcji. Realizacja procesu empowerment - przydawania władzy podopiecznym.

24. Konieczność zmiany w systemie nauczania pedagogicznego, stawianie bardziej na jakość niż na ilość. Mury uczelni powinno opuszczać mniej absolwentów niż dotychczas, ale lepiej wykształconych, przygotowanych do kształtowania postaw na własnym przykładzie. Narzędziami mogą być tu testy predyspozycji dla kandydatów na studia nauczycielskie, „mniejsza liczba miejsc na studiach dla sensowniejszych kandydatów”. Powinno zmierzać się w stronę elitarności studiów pedagogicznych i elitarności zawodu nauczyciela. Aktualnie zbyt późno - na ostatnich latach studiów bądź w pierwszym roku pracy - następuje weryfikacja zawodowa. Nie jest dobrze, jeśli dopiero praca weryfikuje nauczyciela. Jeżeli ocena nauczyciela jest negatywna, to wówczas przede wszystkim szkoda uczniów.

25. Należy prowadzić działania medialne w celu zmiany negatywnego obrazu profesji nauczycielskiej (głos jednego z nauczycieli i przytoczone powiedzenie: „nauczyciel: albo idiota, albo patriota" - przykład niezbyt pozytywny). 
26. Ściślejsza współpraca szkół z uczelniami, stwarzanie uczniom możliwości zaistnienia na uczelni - tworzenie „uniwersyteckich” klas ekonomicznych; ich adepci otrzymują „indeksy”, poznają szkołę wyższą, oswajają się z „dorosłym światem”, czują się nobilitowani. Ze strony uczelni dobrym przykładem działalności „w kierunku szkół” jest współpraca studenckich kół naukowych z placówkami oświatowymi. Innym przykładem współpracy w zakresie „uczelnia dla szkoły” jest przygotowywanie uczniów do olimpiady przedmiotowej z przedsiębiorczości.

\section{Grupy fokusowe 3-4 („przedsiębiorcy”)}

1. Prowadzenie mentoringu, aby facylitator jako mentor towarzyszył uczniowi w szkole, ale był również dostępny podczas jego dalszego uczenia się i rozwoju. Jeżeli nie może tego robić sam, powinien skierować adepta do właściwej osoby, która podejmie się mentoringu. Oznaczałoby to, że szkolenie facylitatora powinno obejmować nauczenie go, jak być mentorem. Przykładem tego rodzaju działań (ang. good practice) jest działalność Fundacji Księcia Karola.

2. W szkoleniu facylitatorów kluczowym elementem powinno być pokazywanie obszarów wsparcia dla ich przyszłej pracy. Biznes i przedsiębiorstwa nie są zainteresowane uczeniem przedsiębiorczości w szkołach (opinia dyrektora szkoły). Również uczelnie uważają szkoły za konkurencję, jeżeli chodzi o uczenie przedsiębiorczości. Obszarem, gdzie najlepiej udaje się wykształcić cechy przedsiębiorcze, jest harcerstwo. Tam młodzi ludzie uczą się samodzielności, zaradności, gospodarności, właściwej organizacji oraz współpracy. Jednak szkoły niezbyt przychylnie patrzą na obecność organizacji harcerskich na terenie szkoły. Traktuje się je jako konkurencję.

3. Kluczową wartość dla programu szkolenia facylitatorów ma współpraca z przedsiębiorstwami, delegowanie z nich pracowników, aby pokazywali, na czym polega działalność gospodarcza, organizacyjna, aktywność w wolontariacie, a także, aby uczyli i inspirowali swoimi sukcesami. Dobrym pośrednikiem w tej współpracy mogą być izby handlowe. Powinno się ustawowo określić zakres i rodzaj świadczenia wsparcia przez biznes na rzecz oświaty. Aktualnie szkoły opierają się na zasobach rodziców uczniów. Przedsiębiorczy rodzice angażują się w życie szkoły, do której chodzą ich dzieci. Kluczowe wydaje się też być wskazanie (stworzenie) korzyści, jakie biznes czerpałby ze współpracy ze szkołą. Mogłyby tu pośredniczyć media, pomagając $w$ tworzeniu pozytywnego wizerunku firm (CSR, PR, CB4), które angażują się we współpracę ze szkołami.

4. Organizowanie wycieczek ze szkoły do firm, zwiedzanie linii produkcyjnych, pokazywanie, jak wytwarza się różne dobra, towary. Istotne jest, aby była to możliwie duża paleta branż, miejsc, typów firm, tak aby uczniowie mogli dopasować coś do siebie, swoich preferencji, gustów, umiejętności. Wizyta w takim miejscu może wówczas obudzić uśpione talenty, wrażliwość, marzenia młodego człowieka.

5. Podniesienie znaczenia pracy w oparciu o zasoby wewnętrzne i zewnętrzne młodego człowieka. Do zasobów wewnętrznych zalicza się m.in. kreatywność, zdolność do pracy w warunkach stresu i przewodzenie, a do zewnętrznych np. umiejętność odnajdywania obszarów wsparcia informacyjnego, emocjonalnego i ekonomicznego. Istotne jest, aby umieć dostrzec istotność obu typów wymienionych zasobów.

${ }^{4}$ Corporate Social Responsibility - Społeczna Odpowiedzialność Biznesu, Public Relations - Promocja Reputacji, Corporate Branding - Marka Pracodawcy. 
6. Praca nad świadomością rodziców; przekonywanie ich, edukowanie na temat tego, jak dużą wartość dla uczniów - w kontekście przedsiębiorczości, a mówiąc szerzej, zaradności życiowej i samodzielności, dojrzewania psychospołecznego - mają lekcje, zajęcia projektowe w terenie. Nauczanie przedsiębiorczości jest kompleksowym programem, a nie tylko wycinkowym przedmiotem. Być może trzeba prowadzić konsekwentną politykę oddziaływania na świadomość rodziców w tej kwestii. Większość z nich nadal bowiem myśli w kategoriach, że liczą się tradycyjne przedmioty szkolne (matematyka, język ojczysty, języki) i uzyskane z nich wyniki w postaci ocen.

7. Rozwijanie preorientacji zawodowej, doradztwo zawodowe w szkołach, testowanie kompetencji uczniów w praktyce.

8. Główny wymóg wobec nauczyciela w kontekście przedsiębiorczości: stwarzanie płaszczyzny do działania dla uczniów. Dostarczanie im projektów, a nie powielanie gotowych, sformatowanych według sztywnych reguł ćwiczeń. Przyzwolenie na nieszablonowe działania młodych ludzi, dopuszczenie wielu prób i popełniania po drodze błędów, bez natychmiastowego oceniania.

9. Warto w oświacie dyskutować na temat tego, jak można wspomagać „klimat” przedsiębiorczości, „zapalić zielone światło” dla ludzi, którzy chcą działać w takim duchu. Należy wskazać, kto miałby ich wspierać. Jeżeli nie będzie to dyrekcja, to powstaje pytanie, czy nie należałoby wprowadzić do szkoły podmiotu audytującego, gotowego mediować w razie konfliktu. Ta „trzecia strona” dawałaby oparcie tym, którzy eksperymentują, a nie mogą liczyć na wsparcie od oficjalnych władz czy rodziców. Wydaje się, że takiej strony (siły) brakuje w obecnym modelu szkoły.

10. Praca nad postawami - odczarowywanie mitu „złego przedsiębiorcy”. Praca z wartościami w szkole. Błędem jest mówienie o jednej przedsiębiorczości na podstawie narzuconego, odgórnego modelu (np. że oznacza ona prowadzenie działalności gospodarczej). Przedsiębiorczość to różne działalności, które zależą od wielu czynników, kontekstu lokalnego, geograficznego i poziomu bezrobocia. Inaczej może być ona realizowana w metropoliach, dużych miastach, a odmiennie w miasteczkach czy na wsi. Warto uwzględnić te różnice w dopasowaniu się do specyfiki miejsc i uczniów, gdzie uczymy przedsiębiorczości.

11. Ograniczające zmiany czynniki polityki edukacyjnej: w polskim szkolnictwie bardzo silna jest pozycja związków zawodowych, które stanowią mocną stronę we wprowadzaniu każdej zmiany systemowej. Należy zatem wziąć pod uwagę, jak duży wpływ na zahamowanie zmian ma taka hegemonia. Istotną prawdą o polskim systemie szkolnictwa jest to, że szkołę traktuje się przede wszystkim jako miejsce pracy dla nauczycieli, a dopiero później jako sferę edukacji młodego pokolenia (w pewnym sensie jest to „rynek pracodawcy”). Z tego powodu w wielu placówkach (niezgodnie z prawem) nie realizuje się Ustawy o systemie oświaty. Jeśli chcemy mówić o sensownej praktyce uczenia przedsiębiorczości, to trzeba zmienić istniejący priorytet beneficjentów systemu pracy w szkolnictwie, który plasuje się obecnie nad beneficjentami usług edukacyjnych.

12. Idea tworzenia klubów „elitarnych nauczycieli”, gromadzących takich pracowników szkoły, którzy chcą się rozwijać i chętnie poświęcają swój czas prywatny na doskonalenie się. Dla nich można organizować spotkania ze znanymi przedsiębiorcami, ludźmi sukcesu w polityce, sporcie czy sztuce, które z jednej strony będą silną inspiracją i formą mentoringu, a z drugiej strony będą dostarczać nauczycielom „punktów kompetencyjnych”, podnoszących ich pozycję na rynku pracy. 
13. Modułowa konstrukcja programu nauczania facylitatora powinna składać się z następujących części: 1. story telling: poznawanie biografii, historii ludzi sukcesu; 2 . analiza case study; 3. realizowanie projektów; 4. prowadzenie gier ekonomicznych; 5. praca z zasobami osobistymi; 6. zapoznanie $\mathrm{z}$ metodami stosowanymi w harcerstwie; 7. działalność w wolontariacie; 8 . nauka budowania społeczności i grupy inspiracji oraz wsparcia; 9. szkolenie „Jak pracować z rodzicami?”.

14. Poszukiwanie oparcia dla własnej przedsiębiorczości w zasobach społecznościowych i rodzinnych. Postawy przedsiębiorcze w istotnym stopniu „dziedziczy się” po własnej rodzinie, dlatego ważnym kierunkiem poszukiwań młodego człowieka może być - wsparta obecnością doradcy zawodowego lub trenera - praca $\mathrm{z}$ własnym genogramem. Byłaby to praca mająca charakter analizy SWOT z akcentem na odnajdywanie ukrytych zasobów we własnym systemie rodzinnym5.

15. Zwiększanie poczucia sprawstwa, istotna rola oddziaływań motywacyjnych na młodych ludzi. Nie należy zapominać, że działania przedsiębiorcze zasadzają się na nadwyżce energii motywacyjnej.

16. Stworzenie możliwości dla szkolącego się facylitatora, aby mógł zdobyć jakiekolwiek doświadczenie w organizowaniu, zarządzaniu lub produkcji. Jest to niezbędne do zbudowania swojego wiarygodnego wizerunku jako osoby przedsiębiorczej wobec przyszłych uczniów.

17. Prowadzenie analizy indywidualnej uczniów pod kątem posiadanych zasobów, doradztwo zawodowe. Młodych ludzi powinno się uczyć, jak badać rynek/branże znajdujące się w polu ich zainteresowań, biorąc pod uwagę, że może to być ich przyszłe miejsce pracy.

18. Aspekt rekrutacyjny: dobierając chętnych do programu szkolenia facylitatorów przedsiębiorczości, należy dokonać selekcji. Do programu powinny trafić osoby posiadające pożądane doświadczenie, odpowiednie cechy osobowe, talenty pedagogiczne lub umiejętności motywowania, inspirowania innych.

19. Szkolenie adeptów na facylitatorów pod kątem umiejętności gromadzenia kapitału relacyjnego - dotyczy m.in. zgromadzonych kontaktów międzyludzkich, znajomości, rekomendacji, wzajemności przysług. Facylitator bowiem jest profesjonalnie mocny wtedy, kiedy posiada szerokie kontakty i może się odwoływać do różnych osób, instytucji, które wspomogą go w prowadzonym procesie edukacyjnym. Dzięki nim może zorganizować spotkanie z uczniami w fabryce, zaprosić znanego przedsiębiorcę na lekcję czy namówić ekspertów do tutoringu itp.

20. Wyjazdy zagraniczne dla adeptów, aby mogli zobaczyć inne rozwiązania systemowe, a także poznać inną mentalność, kultury organizacyjne, styl pracy i model oświaty. Nie chodzi tu o zdobycie nowej wiedzy (będzie ona zapewne skromna, gdyż zgromadzona podczas krótkiego pobytu), lecz o inspirację, inny punkt odniesienia do własnych postaw, wyznawanych wartości, przekonań.

21. Powoływanie fundacji przedsiębiorczości. Facylitatorzy (nauczyciele), pracując w ramach systemu oświaty, posiadają ograniczone pole działania i zasoby. Z fundacji mogliby

\footnotetext{
${ }^{5}$ Genogram jest narzędziem stosowanym w terapii rodzinnej, polega na rozrysowywaniu swojego drzewa genealogicznego. Następnie wspólnie z terapeutą dokonuje się analizy powiązań emocjonalnych z poszczególnymi członkami rodziny. Umożliwia to m.in. odkrycie nieświadomych związków łączących nas z innymi, podobieństw cech, zasobów, doświadczeń. Analiza SWOT (ang. Strengths, Weaknesses, Opportunities, Threats - silne strony, słabe strony, możliwości, zagrożenia) to metoda, dzięki której można określić swoje mocne i słabe strony w kontekście cech osobowych. Połączenie tych dwóch narzędzi pracy w celu poszukiwania potencjałów przedsiębiorczych u danej osoby wydaje się być obiecujące.
} 
otrzymywać niezbędne wsparcie informacyjne, motywacyjne, prawne i inne - takie, jakiego będą potrzebować w swojej pracy.

\section{Wnioski}

\section{Grupy fokusowe nauczycieli}

W trakcie przeprowadzonych debat poświęconych przedsiębiorczości bardzo mocno zaznaczony został wątek odnoszący się do warunków i możliwości pracy nauczyciela. Wiele głosów dotyczyło potrzeby redefinicji roli, statusu i sposobu pracy nauczyciela w polskiej szkole. Ostatecznie z relacji grupy „nauczycielskiej” wyłania się następująca teza: Wobec wyzwania stawianego przed nauczycielem - jakim jest uczenie przedsiębiorczości, oczekuje on wsparcia, zarówno na poziomie systemu, jak i szkoły. Są to oczekiwania dotyczące spraw socjalnych, szkoleniowych, mentoringowych, instruktażowych, zarządczych, a także związanych z gratyfikacją. Rodzi się tu jednak pewien paradoks. Jakkolwiek zrozumiałe jest, że pracownik oczekuje dostarczenia mu odpowiednich narzędzi do realizacji nowego zadania oraz wsparcia w mierzeniu się z nowym wyzwaniem, to równocześnie należy pamiętać, iż mowa tu o specyficznym zadaniu nauczyciela. Postawa przedsiębiorcza, której ekspresja dokonuje się przez dydaktyczne, wychowawcze czy modelujące działanie, zasadza się na aktywności własnej, samodzielnym formułowaniu celów, niezależności myślenia, zdolności stawiania czoła ryzyku, automotywowaniu i posiadaniu wewnętrznego umiejscowienia kontroli. Oczekiwanie, że „ktoś powinien dla mnie coś zrobić, abym poczuł się wystarczająco pewnie, by wdrażać nowatorskie rozwiązania” jest ekspresją postawy pasywnej. Jest w niej implicite zawarte przekonanie: „wciąż nie jestem gotów”, jak również założenie, że to ktoś (wspierająca dyrekcja, urlop stażowy, docenienie w konkursie) dopiero może uczynić ze mnie przedsiębiorczego nauczyciela. Wydaje się to być centralnym ograniczeniem dla rozwoju postaw przedsiębiorczych wśród nauczycieli. Używając kolokwialnej metafory, dydaktycy pracujący w szkołach, na tle uzyskanych w badaniu wypowiedzi, szklankę wypełnioną do połowy wodą postrzegają w kategoriach braku. Taka postawa jest $\mathrm{z}$ gruntu antyprzedsiębiorcza. Okazuje się, że zebrano bardzo mało wypowiedzi, w których dostrzega się aktualne możliwości polskiej szkoły, afirmuje się posiadane zasoby, zauważa się nowe szanse czy wizualizuje wspaniałe, możliwe do uzyskania rezultaty. Natomiast w ogóle nie pojawiły się głosy dotyczące wizji nowej edukacji, w której postawa przedsiębiorcza jest codziennym językiem wartości i elementarnym punktem odniesienia w celach strategicznych nauczania, a nie dodatkowym, mało istotnym przedmiotem, umieszczonym w programie przez ministerstwo.

Kolejną kwestią, która została uwydatniona w czasie dyskusji, było dostrzeżenie konieczności przyjrzenia się relacji nauczyciel - uczeń. Według uczestników grupy fokusowej potrzebna jest dziś redefinicja roli nauczyciela. Pojawiła się również pojedyncza refleksja na temat patriarchalnego modelu obowiązującego w polskiej szkole - otóż wobec wymogów modelowania postaw przedsiębiorczych pozycja nadużywania władzy formalnej jawi się jako kontrproduktywna. Padały też głosy dostrzegające w kontekście uczenia przedsiębiorczości wartość partycypacji uczniów w realizacji programu (jego współtworzenia). Niezbędnym do tego zasobem jest postawa partnerska nauczyciela oraz gotowość do dzielenia się swoją władzą. Chodzi tu o proces określany jako empowerment (Blanchard, 2007), który polega na stopniowym wycofywaniu się przełożonego (w tym wypadku nauczyciela) z pozycji monopolu władzy na rzecz udzielania władzy podwładnym. Swoiście pojmowana władza rozumiana jest tu jako 
możność wpływu, współdecydowania, a także jako walory indywidualnych zasobów i talentów. Partycypacja uczniów w realizacji celów edukacyjnych wiąże się z odpowiedzialnością za to, co ci młodzi ludzie w szkole robią. W tym sensie empowerment - przydawanie władzy uczniom - oznacza, że również oni sami odpowiadają za to, czego się nauczą, w jaki sposób to zrobią i jak wdrożą wiedzę oraz umiejętności wyniesione ze szkoły do własnego życia.

Trzecim ważnym obszarem, którego znaczenie omawiano w grupach fokusowych, był status nauczyciela w kontekście jego prestiżu społecznego, dominującego stereotypu, możliwości zaistnienia w roli modela czy mentora dla podopiecznych. Jest rzeczą zrozumiałą, że negatywny stereotyp tego zawodu przeszkadza nauczycielom. Tymczasem to właśnie bezpośrednio od nich zależy zmiana tego stereotypowego wizerunku. Na podstawie wypowiedzi, które pojawiły się wśród uczestników grup fokusowych, trudno określić, jakiego rodzaju pomocy oczekują uczący. Istnieje bowiem znacząca różnica pomiędzy wprowadzeniem zmiany (działania przedsiębiorczych nauczycieli), następnie poszukiwaniem wsparcia w mediach, działaniach lobbingowych a aktywnością o cechach fasadowych, która z przedsiębiorczością ma jedynie wspólną nazwę. Kryć się tu może warunkowa, samoograniczająca się postawa nauczycieli: „Jeżeli spojrzycie na nas przychylniej i nas docenicie, to bardziej się postaramy (być przedsiębiorczymi)". Warto pamiętać, że cechą proaktywnego działania jest zdolność odroczenia gratyfikacji oraz motywacja wewnętrzna. Innym wątkiem podjętym w trakcie dyskusji był postulat uczynienia szkoły obszarem „silniejszych oddziaływań postawotwórczych”. Dostrzega się bowiem znaczący wpływ domu rodzinnego (rodziców) na kształtowanie światopoglądu dzieci, natomiast nauczyciele nierzadko doświadczają frustracji, ponieważ trudno jest im zainteresować uczniów odmiennym sposobem bycia, systemem przekonań czy wartości. Upraszczając nieco, obraz ten można przedstawić jako przekonanie o umiejscowieniu szkoły - w kontekście kształtowania postaw - na straconej pozycji względem rodziny. Warto zatem zastanowić się, dlaczego tak jest. I znowu, odwołując się do zasad proaktywnego działania, okazuje się, że odpowiedź leży po stronie uczących w szkole. Jeżeli wątpią oni w siłę wpływu szkoły, to warto postawić pytanie o źródła autorytetu nauczyciela, który stanowi podstawowe narzędzie oddziaływania na postawy podopiecznych - to właśnie osoba nauczyciela jest bezpośrednim przedstawicielem szkoły dla ucznia.

Zasygnalizowany tu problem mieszania się postaw i różnej istotności źródeł (dom rodzinny, szkoła, rówieśnicy, kultura popularna, media itp.) stanowi kluczowe zagadnienie w kwestii realizacji celu, jakim jest kształtowanie bardziej przedsiębiorczego, proaktywnego, samodzielnego, aktywnego obywatela. Jak zauważa Szeliga (2007), ci, którzy pragną budować u uczniów postawę przedsiębiorczą, powinni mieć świadomość, że oznacza to skonfrontowanie się z istniejącymi już u młodzieży postawami antyprzedsiębiorczymi. Jako takie wymienia on: doraźność i krótkowzroczność, stadność, eskapizm (emigracja, ucieczka w szarą strefę) oraz fatalizm (Szeliga, 2007: 142). Warto też skonstatować, czy szkoła mimowolnie tych postaw nie wzmacnia.

W zgromadzonych wypowiedziach zastanawiający jest całkowity brak wątku dopasowania organizacyjnego jednostki do grupy. Szkoła jest organizacją o cechach tradycjonalistycznych, stosunkowo sztywną formalnie, wolno przyswajającą zmiany. Nauczyciel nietuzinkowy, oryginalny, pełen inicjatywy, posiadający osiągnięcia w innej sferze zawodowej niż edukacja, przedsiębiorczy funkcjonować będzie w organizacji niezbyt przystającej do jego mentalności i stylu bycia. Jak przestrzega Wypych (2012: 86): „Nie każda organizacja i nie każdy przełożony jest gotów radzić sobie z pracownikiem rozwijającym się. Pracownik poszerzający swoje kwalifikacje i doskonalący się zwiększa również swoje oczekiwania wobec organizacji, oczekuje awansu czy zwiększenia osobistej odpowiedzialności. Niekiedy osoby takie mogą budzić 
niechęć i wzbudzać rywalizację, co ostatecznie może skończyć się utratą pracownika zniechęconego ograniczeniami rozwoju czy niezadowoleniem szefa zazdroszczącego albo też obawiającego się kwalifikacji posiadanych przez podwładnych”. Ów aspekt zagrożenia związanego z „równaniem w dół” wydaje się być nie dość wyraźnie artykułowany przez interesariuszy bardziej przedsiębiorczej szkoły.

\section{Grupy fokusowe przedsiębiorców i ekspertów}

Gdy przyjrzeć się wypowiedziom uczestników tej grupy i porównać je z rekomendacjami w grupie nauczycieli, to tym, co wyłania się z nich na pierwszy plan, jest przeniesienie akcentu uwagi z uczących na uczniów. Przedsiębiorcy i eksperci bardziej pochylali się nad potrzebami uczniów i studentów, a mniej nad nauczycielami. Dobitnie wyrażono to w punkcie 11, dowodząc, że aktualnie - patrząc systemowo, w optyce kultury organizacji - szkoła jest systemem, w którym przede wszystkim dba się o interesy kadry, a dopiero później o interesy podopiecznych. Jeżeli środowisko nauczycielskie (związki zawodowe) nastawione jest na obronę status $q u o$, to trudno oczekiwać w nim gotowości do zmian, które w dłuższej perspektywie mogą przynieść korzyści uczniom. Nauczycielom bowiem proces ten kojarzy się z potencjalnymi zagrożeniami dotyczącymi ich bieżących interesów, gwarancji zatrudnienia, poczucia bezpieczeństwa i konieczności zmiany nawyków mentalnych.

Ważnym wątkiem w dyskusji była analiza roli facylitatora przedsiębiorczości. Uczestnicy postrzegali ją jako alternatywną lub uzupełniającą wobec tradycyjnej funkcji nauczyciela. Tym niemniej nie wykluczyli, że również nauczyciele mogą nabyć kompetencji niezbędnych do jej pełnienia. Dostrzeżono, iż tym, co facyliatator - niebędący absolwentem formalnego systemu formowania nauczycieli - wnosi najcenniejszego, jest jego doświadczenie pozaszkolne. Ma on odgrywać rolę modela, inspiratora, mentora, trenera. Jego siłą jest zewnętrzny background. Jako czynniki wspomagające nauczycieli w stawaniu się facylitatorami przedsiębiorczości wskazano kolejno: stworzenie możliwości praktyk w organizowaniu, zarządzaniu lub produkcji, umożliwienie wyjazdów zagranicznych na staże i wizyty, a także zapraszanie nauczycieli do stowarzyszeń i fundacji zajmujących się przedsiębiorczością.

Jeżeli chodzi o warunki, które mogłyby sprzyjać szkoleniu facylitatorów przedsiębiorczości (pytanie nr $3 \mathrm{w}$ dyskusji), to dostrzeżono czynnik elitarności oraz fakt, że nie każdy powinien zostać facylitatorem. Uznano, iż kandydatów należy poddawać selekcji pod kątem posiadanych predyspozycji. Zauważono też konieczność uzyskania wsparcia ze strony organizacji pozaszkolnych dla osób szkolących się do tej roli. Szkoła uwikłana jest bowiem w szereg uwarunkowań i konfliktów interesów, które blokują krzewienie ducha przedsiębiorczości. Do najcenniejszych zasobów facylitatora należą: odbyte staże, stypendia i wizyty zagraniczne, „Zasilanie” motywacyjne dzięki członkostwu w klubach oraz szkoleniach własnych, zgromadzony kapitał relacyjny, uzyskiwane wsparcie dla swej działalności (bezpośrednie - dyrekcja, współpracownicy; pośrednie - przedsiębiorstwa, media), jak również zbudowane relacje z rodzicami podopiecznych.

\section{Zakończenie}

Uczeń, u którego chcemy rozwinąć cechy przedsiębiorcze, powinien sam doświadczyć, czym jest przedsiębiorczość w działaniu. Facylitator - nauczyciel lub edukator specjalnie przygotowany do tej roli - to osoba, która posiada potencjał do tego, aby pokazywać, na czym 
polega przedsiębiorczość. W niniejszym artykule, na podstawie przeprowadzonych badań jakościowych, starano się zaprezentować, jakie wyzwania stoją przed polską oświatą, jeżeli poważnie myśli się o realnym kształtowaniu postaw przedsiębiorczych oraz przygotowywaniu osób mających odgrywać rolę promotorów przedsiębiorczości. Nieco odmienne poglądy mają na tę sferę ci, którzy uczą w szkołach, oraz przedsiębiorcy, którzy zatrudniają absolwentów. Rozważania te pokazują, że warto konfrontować różne perspektywy w celu ulepszania systemu oświaty w kontekście promowania ducha przedsiębiorczości.

Literatura

References

Blanchard, K. (2007). Przywództwo wyższego stopnia. Blanchard o przywództwie i tworzeniu efektywnych organizacji. Warszawa: Wydawnictwo Naukowe PWN.

Blank, G. (2015, 20 marca). Conducting a focus group. Pozyskano z: www.cse.lehigh.edu/ glennb/mm/ FocusGroups.htm

Eliot \& Associates (2015, 17 lipca). Guidelines for conducting a focus group. Pozyskano z: https://assessment.trinity.duke.edu/documents/How_to_Conduct_a_Focus_Group.pdf

Gregorczyk, S., Romanowska, M., Sopińska, A., Wachowiak, P. (2007). Program nauczania podstaw przedsiębiorczości dla liceum ogólnokształcacego, liceum profilowanego i technikum. Przedsiębiorczość bez tajemnic. Warszawa: Wydawnictwo WSiP.

Morgan, D.L. (1998). The focus group guidebook. Thousand Oaks, London, New Delhi: Sage Publications. Strona programu Perspective (2015, 4 października). Pozyskano z: http://www.perspectiveproject.eu/pl Szeliga, P. (2007). Chwasty na polu przedsiębiorczości, czyli czego w szkole nie uprawiać. W: P. Wachowiak, M. Dąbrowski, B. Majewski (red.), Kształtowanie postaw przedsiębiorczych a edukacja ekonomiczna. Warszawa: Fundacja Promocji i Akredytacji Kierunków Ekonomicznych.

Wypych, M. (2012). Warunki skuteczności osób proaktywnych w organizacjach. W: M. Motyka, J. Pawlak (red.), Podmiotowośćczłowieka w organizacji. Kraków: Wydawnictwo Uniwersytetu Ekonomicznego.

Mariusz Makowski, psycholog społeczny, dr nauk humanistycznych związany z Uniwersytetem Ekonomicznym w Krakowie od 2005 r. Jego obszar eksploracji teoretycznych i badawczych koncentruje się na: problematyce mediów, kształtowaniu postaw oraz wpływie społecznym nadawców masowych. Od kilkunastu lat zaangażowany jest we współpracę z prasą, radiem i telewizją na polu edukacyjnym. Swoje najbliższe plany badawcze wiąże ze zgłębieniem zagadnień poznawczych i emocjonalnych konsekwencji percepcji obrazów fotograficznych.

Mariusz Makowski, PhD, social psychologist, affiliated with University of Economics in Cracow since 2005. Area of theoretical and research explorations concentrates on: media, attitudes' development and social influence created by mass media. For many years he has been cooperating in the field of education with the media: press, radio and TV. Future research interests are connected to cognitive and emotional consequences of photography perception.

\section{Adres/Address:}

Uniwersytet Ekonomiczny w Krakowie

Katedra Psychologii i Dydaktyki

ul. Rakowicka 27

31-510 Kraków, Polska

e-mail: makowski@uek.krakow.pl 